\title{
Economic and Environmental Benefits of Reducing Standby Power Loss in DVD/VCD Players and Copiers in China
}

\author{
Lin Jiang \\ Lawrence Berkeley National Laboratory
}

Li Tienan, Li Aizhen, and Zhang Guoqing,

China Certification Center for Energy Conservation Products 


\section{Introduction}

With the popularization of household electrical appliances and the rapid development of office automation and networking, a huge number of consumer electronic devices, computers, copiers, and fax machines have been put into use in China over the last two decades. These products almost all use a certain amount of standby power - the power that is consumed when a device is connected but not performing its primary function.

The rapid growth of standby energy consumption due to these products - and the consequent environmental problems - has attracted more and more attentions from researchers and from many government and international agencies. Numerous countries have developed policies and measures to restrict and reduce standby energy consumption (US EPA, 2004, IEA, 2001, and GEEA, 2004). However, standby energy consumption is still a new concept for Chinese consumers and the phenomenon of "unconscious waste of energy" is still very common in the people's daily life and work. With the goal of reducing China's standby energy consumption, China Certification Center for Energy Conservation Products (CECP) and the Lawrence Berkeley National Laboratory (LBNL) have, under the sponsorship of the Energy Foundation (EF), entered into a collaboration to develop technical requirements for CECP's labeling program for consumer electronics and office equipment. These technical requirements will be used to qualify products for CECP's energy efficiency endorsement label in China.

In the phase I of this collaborative project, CECP and LBNL conducted technical and economic research on televisions and printers in China. Based on the results of this research, CECP developed specifications for, and carried out corresponding energy conservation certifications for these two products. CECP's standby power certification program has made impressive gains in China. Leading manufacturers, such as Haier, Hesons, TCL, Chuangwei, Lenovo, EPSON, Fujitsu, and Brother have participated in CECP's certification activities. Media events organized by CECP have greatly improved the country's awareness of standby power loss. Reducing standby power loss has been formally incorporated into China's energy efficiency policy portfolio and in China's collaboration with the international community on the subject of energy efficiency (IEA, 2001).

In phase II of the program, CECP's main task was to assess the market for DVD/VCD (Digital Versatile/Video Disc and Video Compact Disc) players and copiers to analyze the economic and technical benefits of energy conservation potential, and to develop technical specifications for DVD/VCD players and copiers, with technical assistance from LBNL. Having built on the success of Phase I, CECP paid great attention to the appraisal of market conditions and the economic and environmental benefits of reducing standby power loss in DVD/VCD players and copiers, and solicited inputs from stakeholders before finalizing the product certification requirements. This paper summarizes the expected energy conservation and environmental benefits due to the implementation of certification programs for DVD/VCD players and copiers in China. 


\section{Models and Parameters}

\section{Description of model}

The model used for this analysis was based on a model developed at LBNL, appropriately modified to reflect the characteristics of different products. The major input parameters include market data (production, sales volume, export and import volume, and stock), product performance parameters (such as the patterns of use, service life, and unit energy consumption), electricity tariffs, and pollutant emission factors. The major outputs include energy and cost saving estimates and avoided pollution (carbon dioxide $\left(\mathrm{CO}_{2}\right)$, sulfur dioxide $\left(\mathrm{SO}_{2}\right)$, nitrogen oxides $\left(\mathrm{NO}_{\mathrm{x}}\right)$, and particulates).

\section{Data collection}

Given the challenges in obtaining both market and product performance data, CECP, with the advice from LBNL, pursued a variety of data collection channels as described below.

- Manufacturers

Since there is no single source of data for most of these products, a simple way to obtain data is to apply directly to manufacturers. In China, some products (especially household electrical appliances) are mainly manufactured by a small number of manufacturers, so it is relatively easy to obtain market data and other parameters from these few manufacturers.

- Industrial associations

We have visited some industrial associations such as the China Association of Lighting Industry and the China Household Electrical Appliances Association to obtain the relevant parameters.

- Laboratories

Some laboratories including the China National Household Electrical Appliances Test Center, the National Computer Test Center, the National Copier Test Center, the Research Institute of Telecommunications Transmission of the Ministry of Information Industry, and the CEPREI Laboratory have helped CECP collect and organize some data obtained during regular product tests.

- National statistical yearbooks

The outputs of some products such as copiers can be obtained from national statistical yearbooks.

- Questionnaires and actual measurements

During the research, data about the patterns of the use of some products were obtained by means of questionnaires. Data about the standby energy consumption and service energy consumption of office equipment have been obtained through actual sample measurement in Guangzhou and Beijing. 
- Other channels

Some data were obtained from periodicals, magazines, and Internet searches.

- Expert forecast

Some data that cannot be obtained from above-mentioned channels were acquired through consultations with experts.

\section{Electricity tariff}

Table 1 shows the electricity tariffs for residential households, commercial buildings, ordinary industries, and big industries in Beijing, Anhui, Hunan, Guizhou, Hebei, Zhuhai, Leshan, Shucheng, Yanzhou, Nantong, Sanming, and the coverage of Beijing-Tianjin-Tangshan Power Grid in 1999. The result of simple average calculation indicates that China's average electricity tariff in 1999 was RMB0.57 per $\mathrm{kWh}$. This average rate was used in the current analysis.

Table 1: Statistics on power rates in selected parts of China, 1999

\begin{tabular}{|l|c|c|c|c|c|}
\hline \multirow{2}{*}{ Province/city } & \multicolumn{5}{|c|}{ Power rate in 1999 (RMB/kWh) } \\
\cline { 2 - 6 } & Households & Non-households & Business & $\begin{array}{l}\text { Ordinary } \\
\text { industry }\end{array}$ & $\begin{array}{c}\text { Big } \\
\text { industry }\end{array}$ \\
\hline Beijing & 0.39 & 0.61 & 0.61 & 0.54 & 0.40 \\
\hline $\begin{array}{l}\text { Beijing-Tianjin-Tangshan } \\
\text { Power Grid }\end{array}$ & 0.22 & 0.33 & & 0.29 & 0.20 \\
\hline Zhuhai City & 0.66 & & 1.01 & 0.78 & 0.60 \\
\hline Anhui Province & 0.51 & 0.69 & 0.96 & 0.59 & 0.48 \\
\hline Hunan Province & 0.50 & 0.76 & 0.98 & 0.55 & 0.44 \\
\hline Guizhou Province & 0.40 & 0.51 & 0.75 & 0.41 & 0.32 \\
\hline Hebei Province & 0.37 & 0.53 & 0.67 & 0.50 & 0.35 \\
\hline Leshan City & 0.33 & 0.51 & & 0.41 & 0.33 \\
\hline Shucheng County & 0.51 & 0.69 & 0.96 & 0.59 & 0.48 \\
\hline Yanzhou City & 0.42 & 0.65 & & 0.56 & 0.47 \\
\hline Nantong City & 0.52 & 0.79 & 0.90 & 0.66 & 0.47 \\
\hline Sanming City & 0.70 & 0.41 & 0.72 & 0.50 & 0.42 \\
\hline Average & 0.46 & 0.59 & 0.84 & 0.53 & 0.41 \\
\hline Grand average & & & 0.57 & & \\
\hline
\end{tabular}

\section{Emission factors}

CECP adopted the emission factor data used by the World Bank during its appraisal of Chinese projects in 1994. The emission factors of carbon, nitrides, sulfides, and solid particulates are $339 \mathrm{~g} / \mathrm{kWh}, 4.07 \mathrm{~g} / \mathrm{kWh}, 53.10 \mathrm{~g} / \mathrm{kWh}$ and $24.80 \mathrm{~g} / \mathrm{kWh}$, respectively (World Bank, 1994).

\section{Product life and retirement rates}

The average life of a class of products is determined to be $\mathrm{N}$ years according to market investigation and/or expert forecast. To simplify the analytic model, we suppose that all 
the products sold in a year will be retired in year $\mathrm{N}+1$, and all the products will be in normal use with no retirement before the end of their service life. For example, on the supposition that the lifetime of a product is five years, the retirement function for this product is as shown in figure 1.

Figure 1: Survival function for a product with a lifetime of five years.

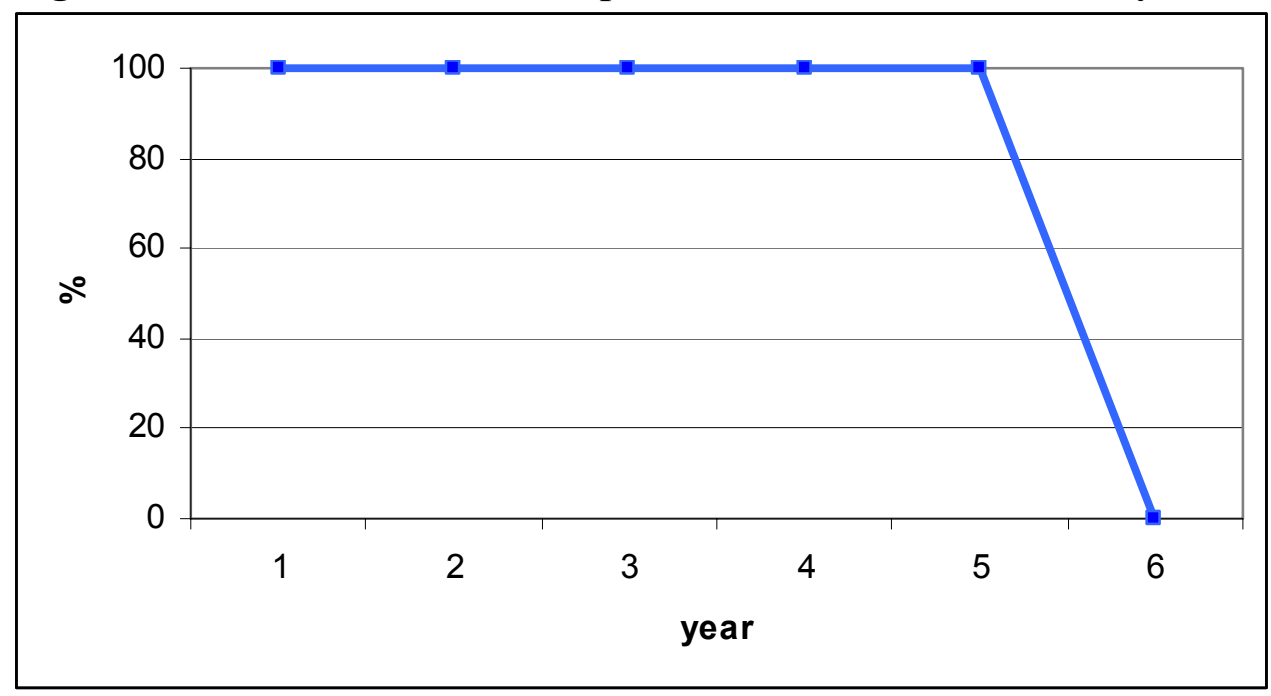

\section{Energy Conservation Potential for DVD/VCD Players}

\subsection{Overview of the DVD/VCD players market}

China is the largest market for consumer electronic appliances in the world. With the improvement in peoples' living standards, and with the popularization of wide-screen TV and home theater systems, the demand for DVD/VCD players is growing rapidly. According to research conducted during this project, the market for audio-visual players has changed drastically since 2001, with DVD technology gaining increasing market share and VCD players being gradually phased out. The sales of DVD players has grown particularly quickly from 1999 forward. While the demand of audio-visual players in 2002 was almost equal to that in 2001, the sales of ordinary VCD players dropped. Many manufacturers have ceased producing VCD players and have switched to producing DVD players. In the total sales of 18.3 million video-disc players, the sales of DVD players was about 11 million in 2002, compared with 4.1 million in 2001 -- a growth of $168 \%$. It is expected that by 2004 , VCD players will exit from the Chinese market, replaced entirely by DVD players.

At present, there are many brands of DVD players. Domestic brands are dominant in market. The top ten domestic brands, including Shinco, Bubukao, Nintaus, Amosonic, and SVA, have a collective market share of $87 \%$. In this field, Shinco is the 
leading producer, with a market share of nearly $30 \%$; the top three brands together command about $60 \%$ of the DVD market in China. The market for DVD players will be relatively stable in the near future, with an expected growth rate of $4.7 \%$.

Table 2: Market share of leading brands of DVD/VCD players in China, 2002

\begin{tabular}{|c|c|c|c|c|c||}
\hline \multicolumn{3}{|c|}{ DVD } & \multicolumn{3}{c|}{ VCD } \\
\hline \multirow{2nnnnnyy}{*}{ Rank } & Brand & $\begin{array}{c}\text { Market Share } \\
\%\end{array}$ & Rank & Brand & $\begin{array}{c}\text { Market Share } \\
\%\end{array}$ \\
\hline 1 & SHINCO & 28.07 & 1 & BUBUKAO & 21.43 \\
\hline \hline 2 & BUBUKAO & 14.11 & 2 & NINTAUS & 12.42 \\
\hline \hline 3 & NINTAUS & 9.35 & 3 & AMOSONIC & 10.29 \\
\hline 4 & AMOSONIC & 9.01 & 4 & SHINCO & 6.07 \\
\hline 5 & SVA & 8.42 & 5 & SAST & 5.89 \\
\hline \hline 6 & LG & 5.19 & 6 & MALATA & 5.65 \\
\hline \hline 7 & SAST & 4.36 & 7 & YUXING & 4.19 \\
\hline \hline 9 & MALATA & 3.66 & 8 & MAGICSOUND & 3.19 \\
\hline \hline 10 & PANASONIC & 2.95 & 9 & CHUANGWEI & 3.04 \\
\hline \hline
\end{tabular}

There are several foreign brands of DVD players in the market, such as Sony, Philips, Panasonic, LG, and Pioneer. These foreign manufacturers mainly produce high-end DVD players, and their collective market share is about 13\%. Although foreign brands do not have high market share, to some extent, they set the trend in terms of technology development for DVD players.

\subsection{Analysis of the energy consumption of DVD/VCD players}

In collaboration with CECP, CEPREI Laboratory in Guangzhou tested 90 DVD/VCD players for their power consumption in 2001. The test results indicate that the average standby energy consumption of DVD/VCD players is about $9.5 \mathrm{~W}$.

The US Energy Star Program (US EPA, 2004) requires that the standby energy consumption of a DVD player not be more than $1 \mathrm{Wh} / \mathrm{h}$ in order to qualify for the Energy Star label. The distribution of the standby energy consumptions of China's DVD/VCD products is shown in Table 3. Only 12 of the tested DVD/VCD players meet the requirement of Energy Star, accounting for $13.3 \%$. In other words, $86.7 \%$ of the Chinese products do not currently meet the Energy Star requirement.

Table 3: Distribution of standby energy use of DVD/VCD players

\begin{tabular}{|c|c|c|}
\hline Energy use in standby mode & Number & Proportion \\
\hline$\leq 1 \mathrm{w}$ & 12 & $13.3 \%$ \\
\hline
\end{tabular}




\begin{tabular}{|c|c|c|}
\hline $1<$ stand $\leq 3 \mathrm{w}$ & 20 & $22.2 \%$ \\
\hline $3<$ stand & 58 & $64.5 \%$ \\
\hline
\end{tabular}

\subsection{Analysis of the energy conservation potential of DVD/VCD players}

\section{Basic parameters and assumptions}

- Sales volume: The annual sales volumes in 2003 through 2020 are calculated on the basis of the annual outputs in 1994-1996, the domestic sales volumes in 1996-1997, and the domestic sales volumes in 2002. The growth rate from 2003 to 2020 is assumed to be $4.7 \%$.

- Current market share of energy conservation products: According to the data under investigation, the market share of energy conservation products is $13.3 \%$ as indicated in Table 3.

- Stock: Since DVD/VCD players saw no rapid development until 1996, the sales volumes in 1994-1995 were very small. On the supposition that the stock on the market in 1994 was just the sales volume in that year, the annual stock on the market in 1995-2020 are calculated after adding the sales volume and deducting the stock retired in each year.

- Patterns of use: According to the survey data collected for this project, the daily service period of a DVD/VCD player is 2.47 hours and the daily standby period is 1.75 hours.

- Standby energy consumption: According to the 2001 CEPREI test data, the standby energy consumption of a DVD/VCD player in its normal state is $9.5 \mathrm{~W}$, and it is assumed that the standby energy consumption will be $1 \mathrm{~W}$ after the energy conservation program is implemented.

- Goal of the program: The goal of the program is to increase the market shares of energy conservation products to $10 \%$ in $2003,20 \%$ in $2004,40 \%$ in $2005,60 \%$ in $2006,75 \%$ in $2007,80 \%$ in 2008 and thereafter.

- Product life and retirement rates: The estimated average life is five years. It is assumed that all products will be retired at the end of last year of their service life.

\section{$\underline{\text { Economic and environmental impact }}$}

If CECP can launch the program of energy conservation certification for DVD/VCD players in 2003 with $1 \mathrm{~W}$ adopted as the certification value for standby power consumption, it is estimated that 635 million $\mathrm{kWh}$ of electric energy can be saved in 2020, the accumulated electricity savings from 2003 to 2020 would add up to 6.5 billion $\mathrm{kWh}$.

Given that minimal cost increases are expected due to newer technologies to comply with the $1 \mathrm{~W}$ requirement for standby power, Chinese consumers would reap substantial cost savings due to the reduced electricity waste. Based on the average electricity tariff in 1999, the total cost savings from 2003 to 2020 would amount to 3.7 billion RMB. 
Figure 2: Electricity saving estimates due to DVD labeling, 2003-2020

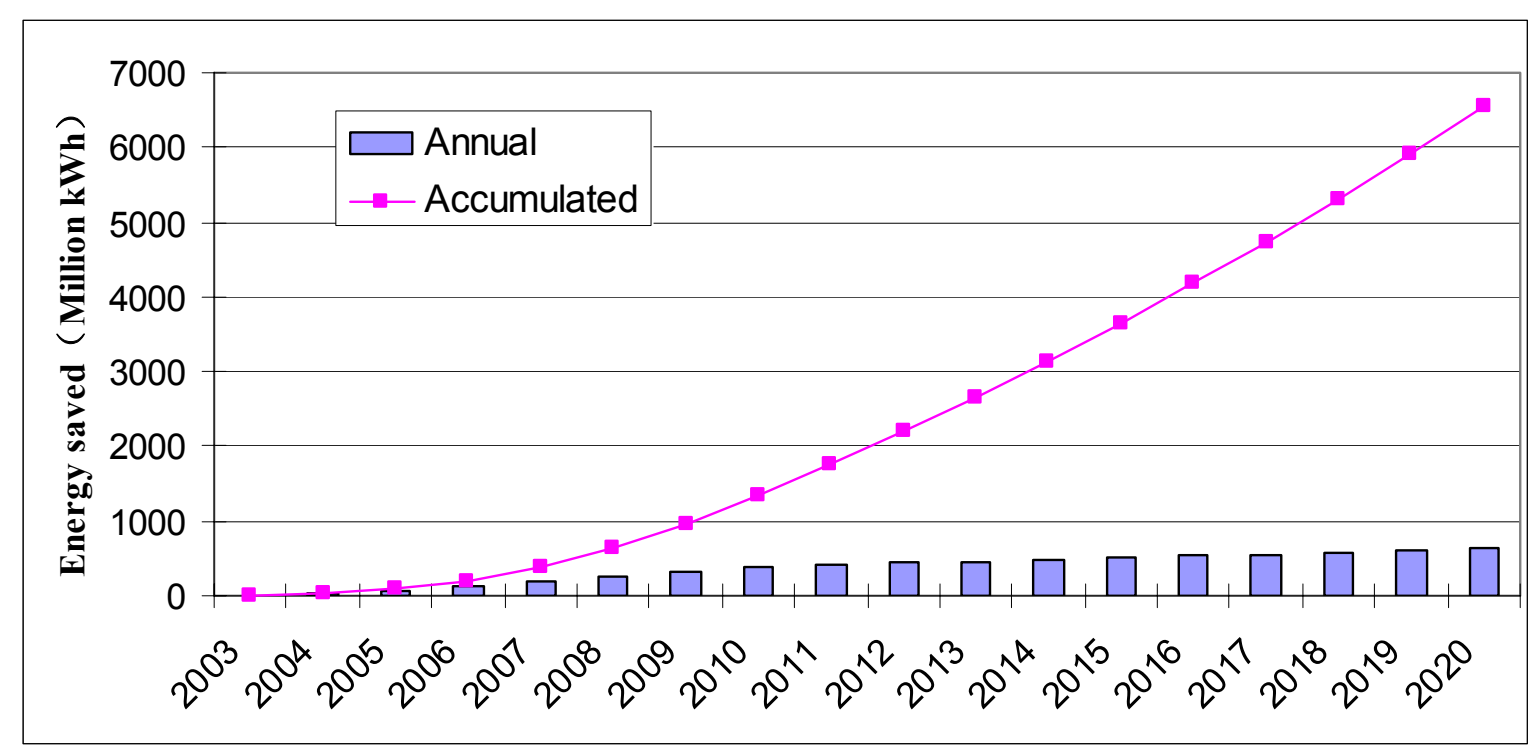

Figure 3: Consumer cost saving estimates due to DVD labeling, 2003-2020

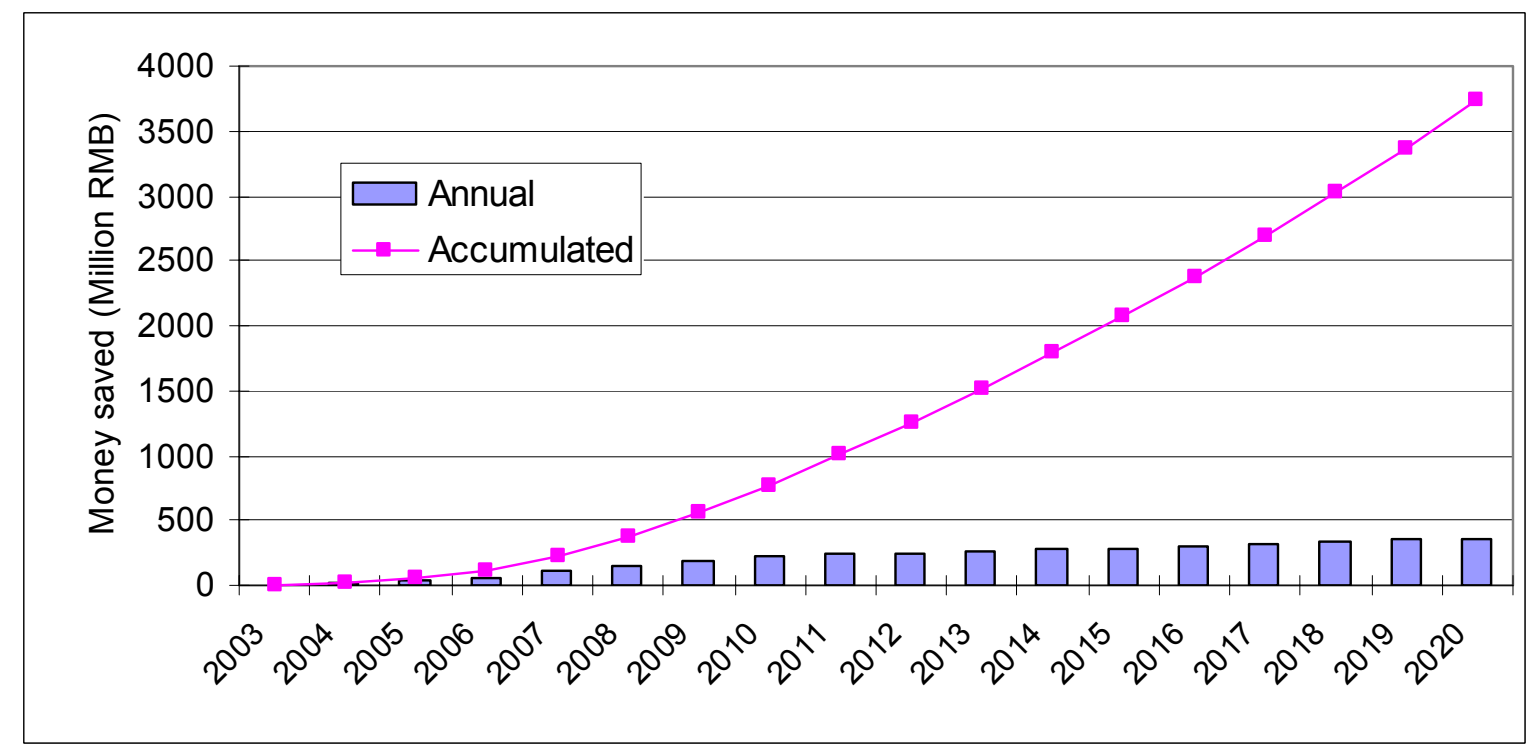

Such electricity savings would also translate into large reductions in pollution associated with electricity generation, given that coal-powered plants still dominate China's generation fleet. According to data on China's emission factors estimated by the World Bank, the reduction of carbon emissions due to the DVD certification program would reach 215 thousand tons of carbon in 2020, and the accumulative reduction between 2003 and 2020 would reach 2.2 million tons of carbon.

Emissions of associated pollutants such as $\mathrm{NO}_{\mathrm{x}}, \mathrm{SO}_{2}$, and solid particulates would also be reduced by 2.6 thousand tons, 33.7 thousand tons, and 15.8 thousand tons in 2020 , respectively. The accumulated reductions would reach 26.7 thousand tons for $\mathrm{NO}_{\mathrm{x}}, 347.9$ thousand tons for $\mathrm{SO}_{2}$, and 162.5 thousand tons for solid particulates, respectively, from 2003 to 2020. 
Figure 4: Carbon emissions reductions due to DVD labeling

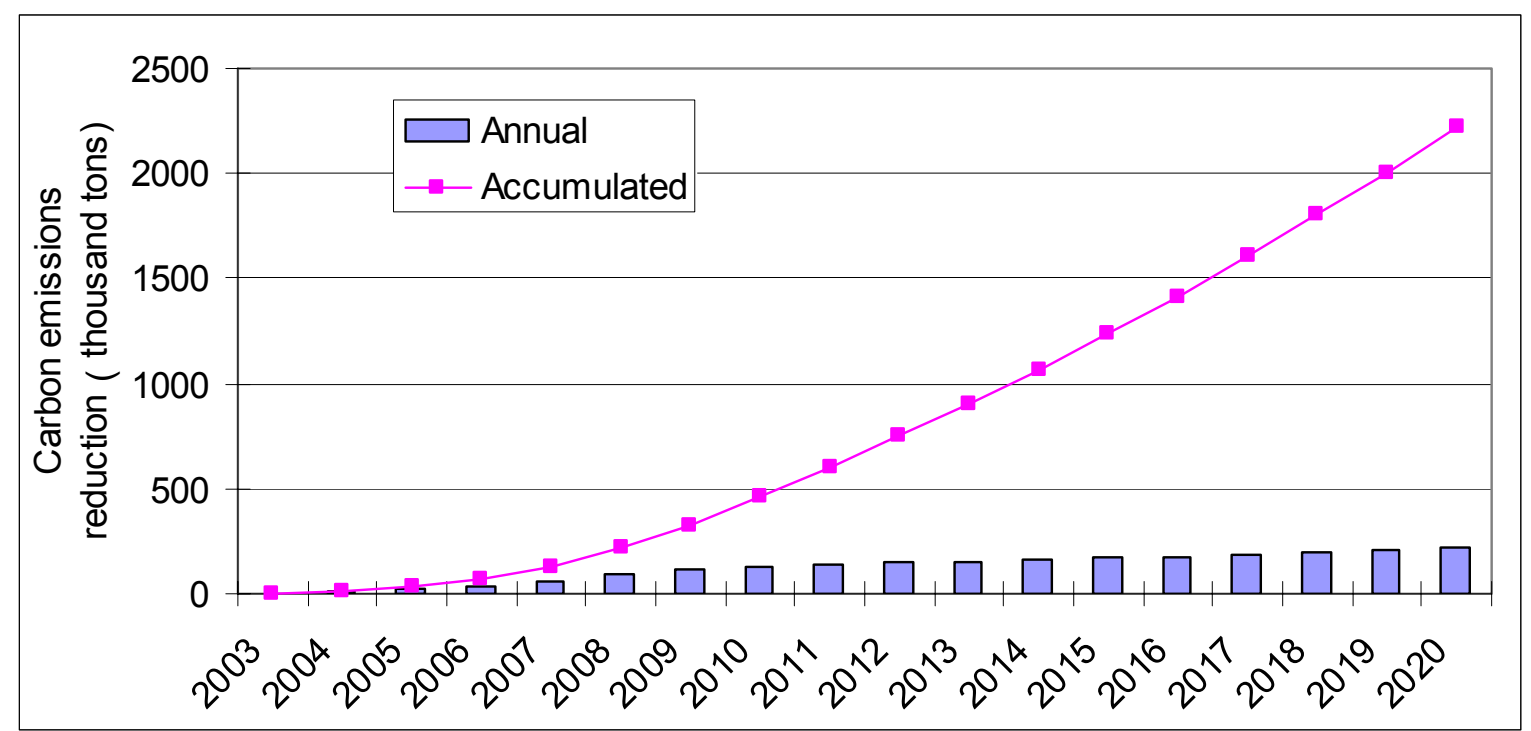

Figure 5: $\mathrm{NO}_{\mathrm{x}}$ emissions reductions due to DVD labeling

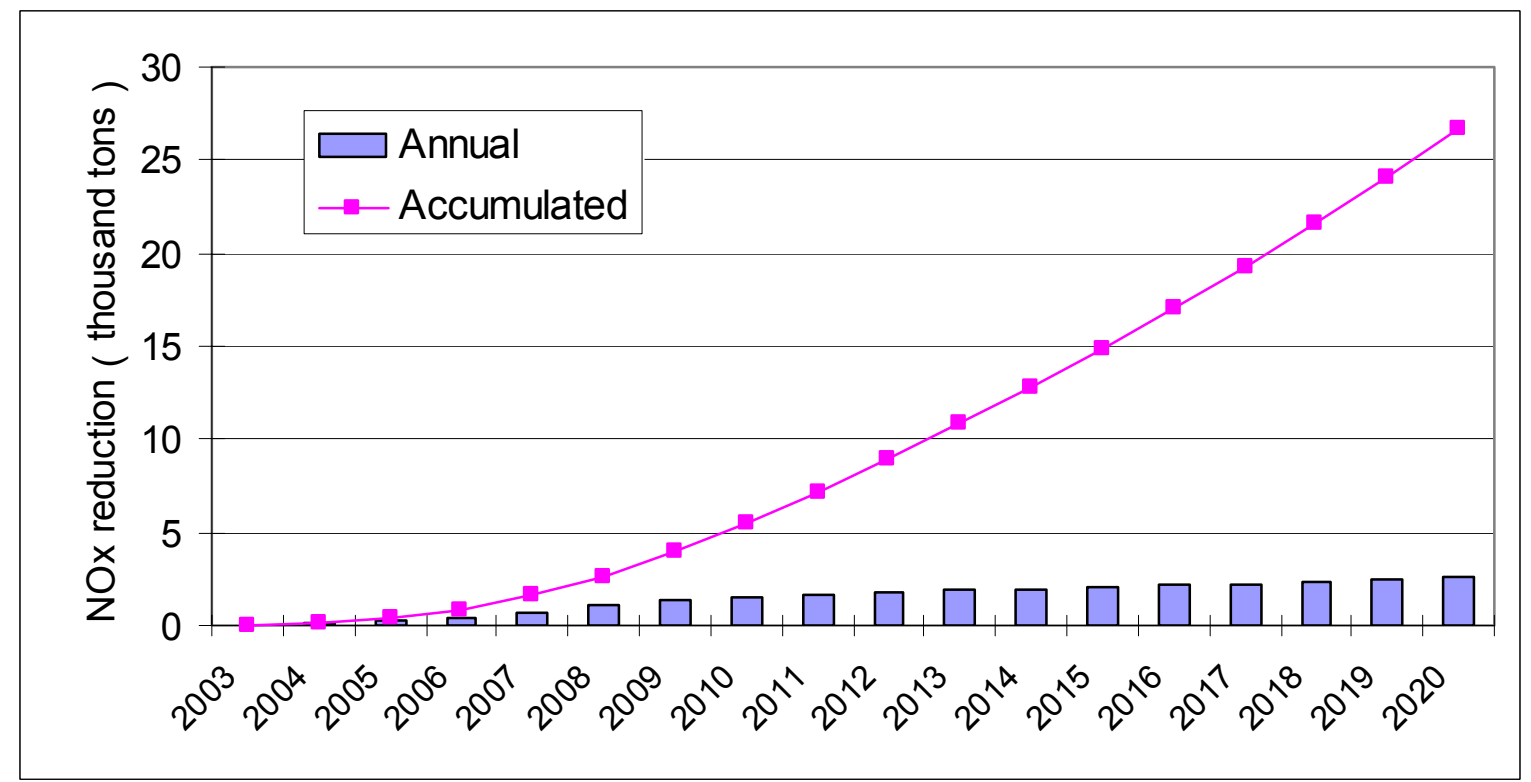


Figure 6: $\mathrm{SO}_{2}$ emissions reductions due to DVD labeling

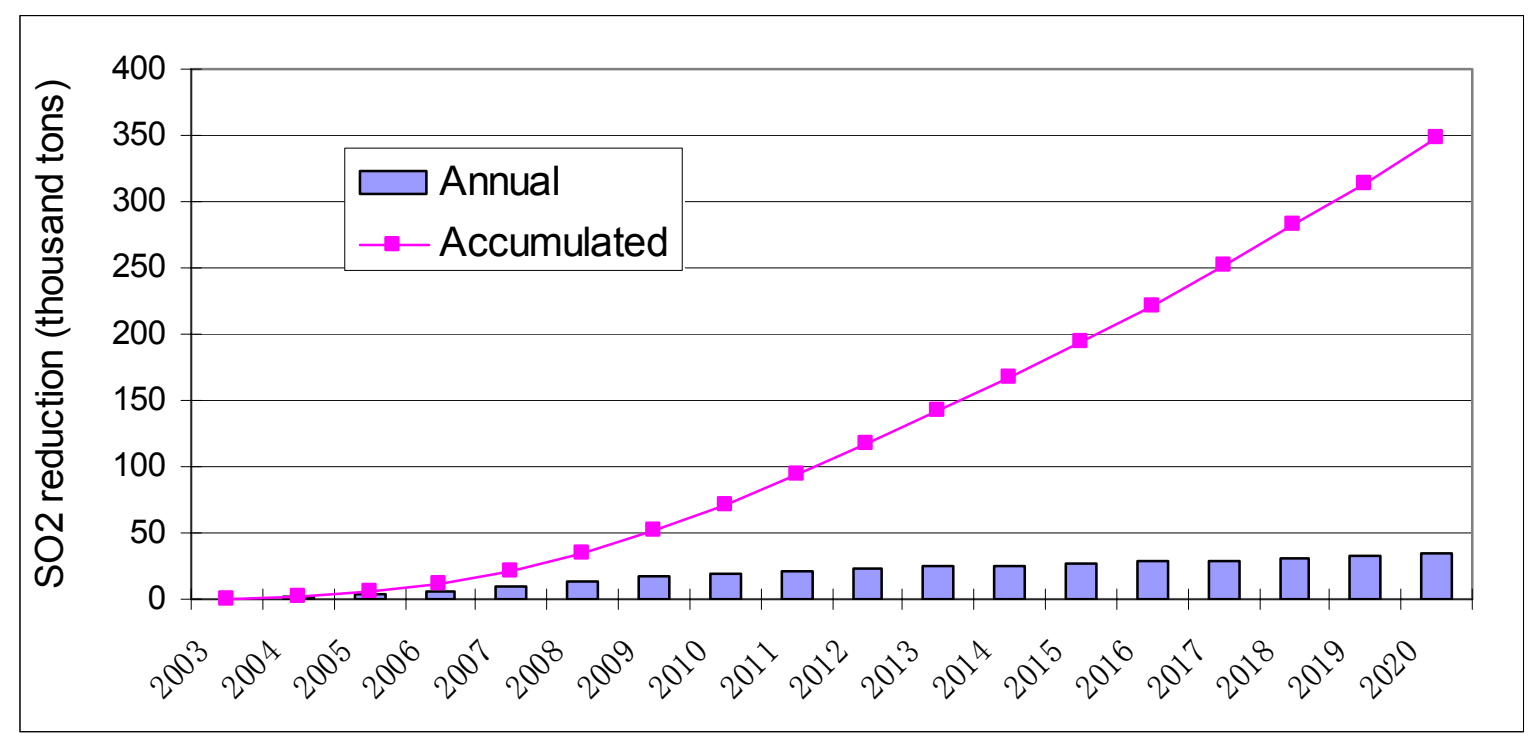

Figure 7: Particulates emissions reductions due to DVD labeling

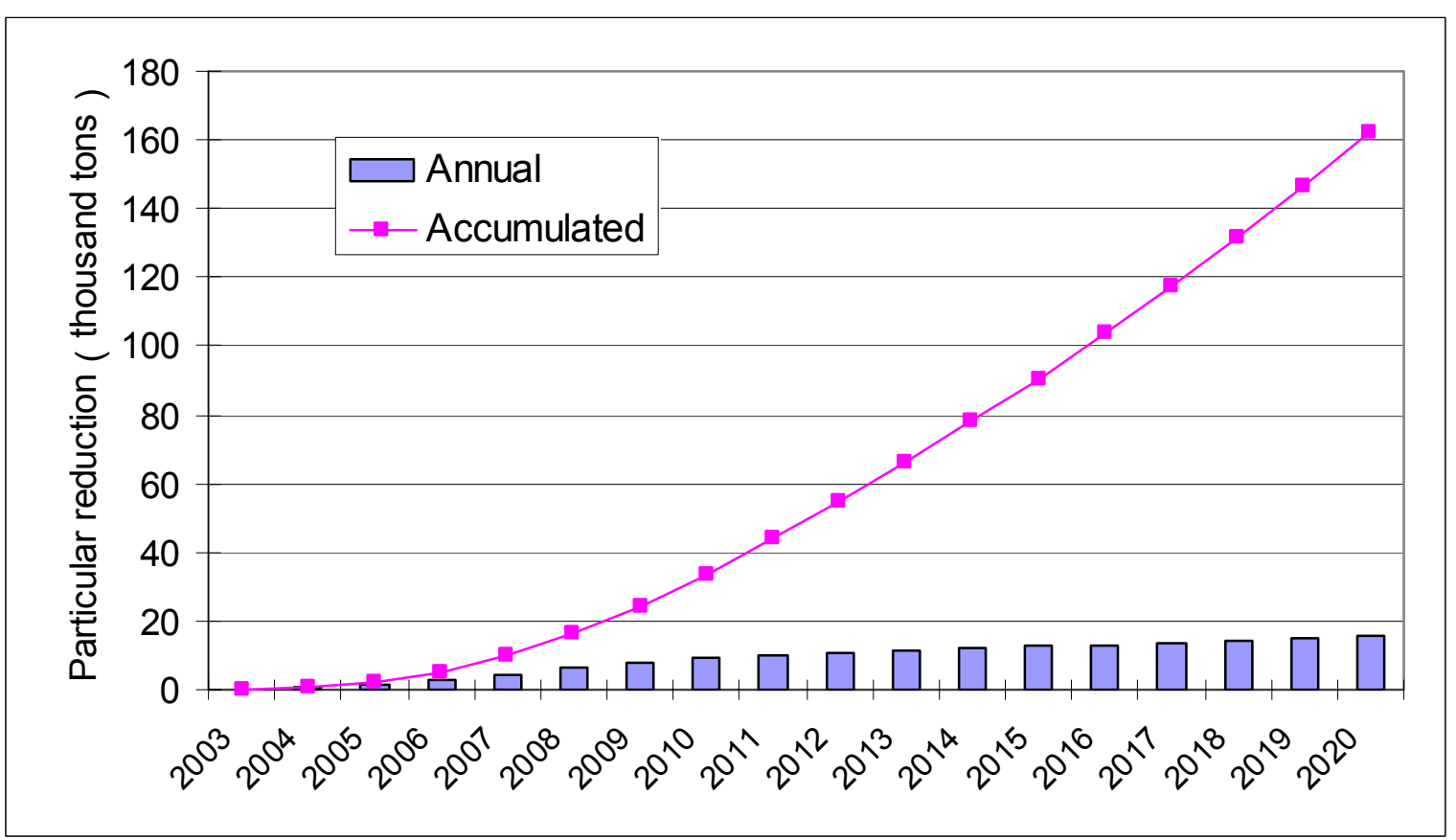




\section{Energy Conservation Potential for Copiers}

\subsection{Overview of the Chinese copier market}

Copier sales have grown rapidly in recent years in China. This is related to the rapid expansion of China's economic activities in the last few years, partly stimulated by the vigorous growth in fixed asset investments. Prices of copiers have also declined, making them more affordable for many small businesses. According to China industrial statistics (NBS, 2003), 2.1 million copiers were sold in China in 2002.

Table 4: Market share of copiers by printing speeds, in 2002

\begin{tabular}{|c|c|c|c|c|}
\hline Speed & Low & Medium & High & Total \\
\hline Proportion & $46.3 \%$ & $38.4 \%$ & $15.4 \%$ & $100 \%$ \\
\hline
\end{tabular}

The main purchasers of low-speed copiers were rapidly rising small business enterprises; the main purchasers of medium and low-speed copiers were government agencies, non-government institutions, and medium-sized enterprises; and the main purchasers of high-speed copiers were large enterprises and copying and printing service stores. The sales of high-speed copiers were mainly concentrated in the developed areas in east China. However, the best-sellers were small low-speed copiers.

\subsection{Analysis of the energy consumption of copiers}

The result of tests of 15 copiers conducted by CEPREI in 2002 indicates that the average standby energy consumption is $29.2 \mathrm{Wh} / \mathrm{h}$. See Table 5 for the distribution of standby energy consumption of China's copiers. The US Energy Star Program requires that standby energy use of a copier should be no more than $25 \mathrm{~W}$. Only seven tested copiers meet this requirement, accounting for $46.7 \%$ of the sample, while $53.5 \%$ of the sample fail to meet the Energy Star requirement.

Table 5: Distribution of standby energy consumption of copiers

\begin{tabular}{|c|c|c|}
\hline Standby energy consumption & Number & Proportion \\
\hline$\leq 25 \mathrm{w}$ & 7 & $46.7 \%$ \\
\hline $25<$ stand & 8 & $53.3 \%$ \\
\hline
\end{tabular}

\subsection{The potential for electricity savings and pollution reduction of copiers in China}

\section{Basic parameters and assumptions}

- Sales volume: Data prior to 2002 were obtained from China Statistical Yearbooks. Sales in 2004 was based on the data provided by Sharp. The growth rate between 2002 and 2012 is assumed to be $12.6 \%$, the growth rate in 2013-2020 is assumed to be 5\%.

- Current market share of energy conservation products: In the tested copiers, the proportion of energy conservation products is $46.7 \%$.

- Stocks: stocks of copiers were estimated based on annual sales and retirement 
rates.

- Patterns of use: According to the results of a survey conducted during this project, the daily service period of a copier is 2.75 hours and the daily standby period is 6 hours.

- Standby energy consumption: The standby energy consumption is $29.2 \mathrm{~W}$ on average in the business-as-usual case. After the energy conservation program is implemented, the standby energy consumption will be $25 \mathrm{~W}$.

- Goal of the program: The goal of the program is to increase the market share of energy conservation products to $10 \%$ in $2003,15 \%$ in $2004,20 \%$ in $2005,25 \%$ in $2006,30 \%$ in $2007,40 \%$ in 2008 , and $45 \%$ in $2009-2020$.

- Product life and retirement rates: The estimated average lifetime for copiers is five years. It is assumed that the copier will be retired at the end of its lifetime.

\section{Economic and environmental impact}

If CECP can launch the program of energy conservation certification for copiers in 2003 , it is estimated that 906 million $\mathrm{kWh}$ of electricity could be saved in 2020 , if $25 \mathrm{~W}$ is adopted as the energy conservation appraisal value. Over the period of 2003-2020, the cumulative electricity savings could reach 6.4 billion $\mathrm{kWh}$. Based on the average electricity tariff in China in 1999, the savings would amount to over 500 million RMB in 2020 alone and 3.6 billion RMB from 2003 to 2020.

Figure 8: Electricity savings due to copier labeling, 2003-2020

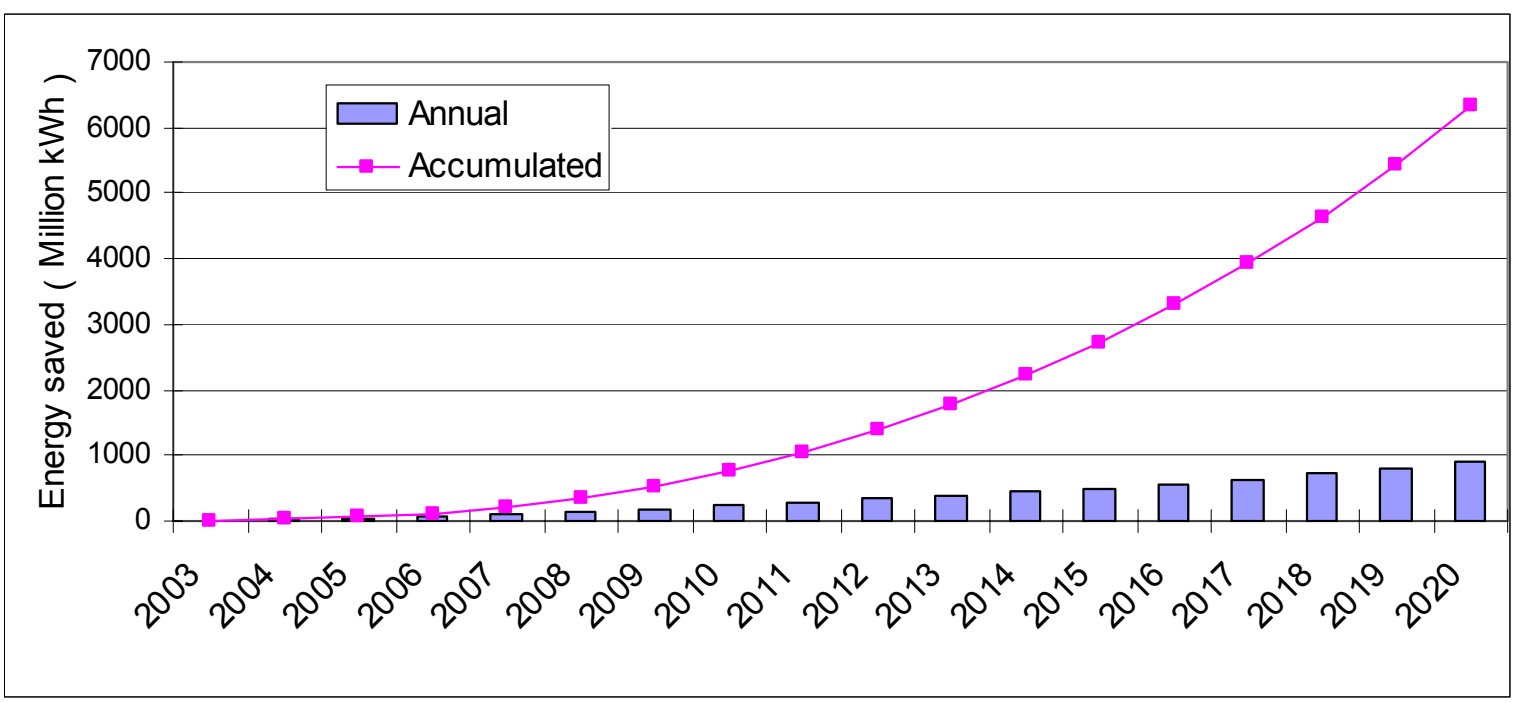

The estimated reduction in electricity usage would also reduce the emissions of various pollutants associated with power generation. Carbon emission reduction would be 307 thousand tons in 2020, and reach 2.2 million tons from 2003 to 2020. 
Figure 9: Electricity cost savings due to copier labeling, 2003-2020

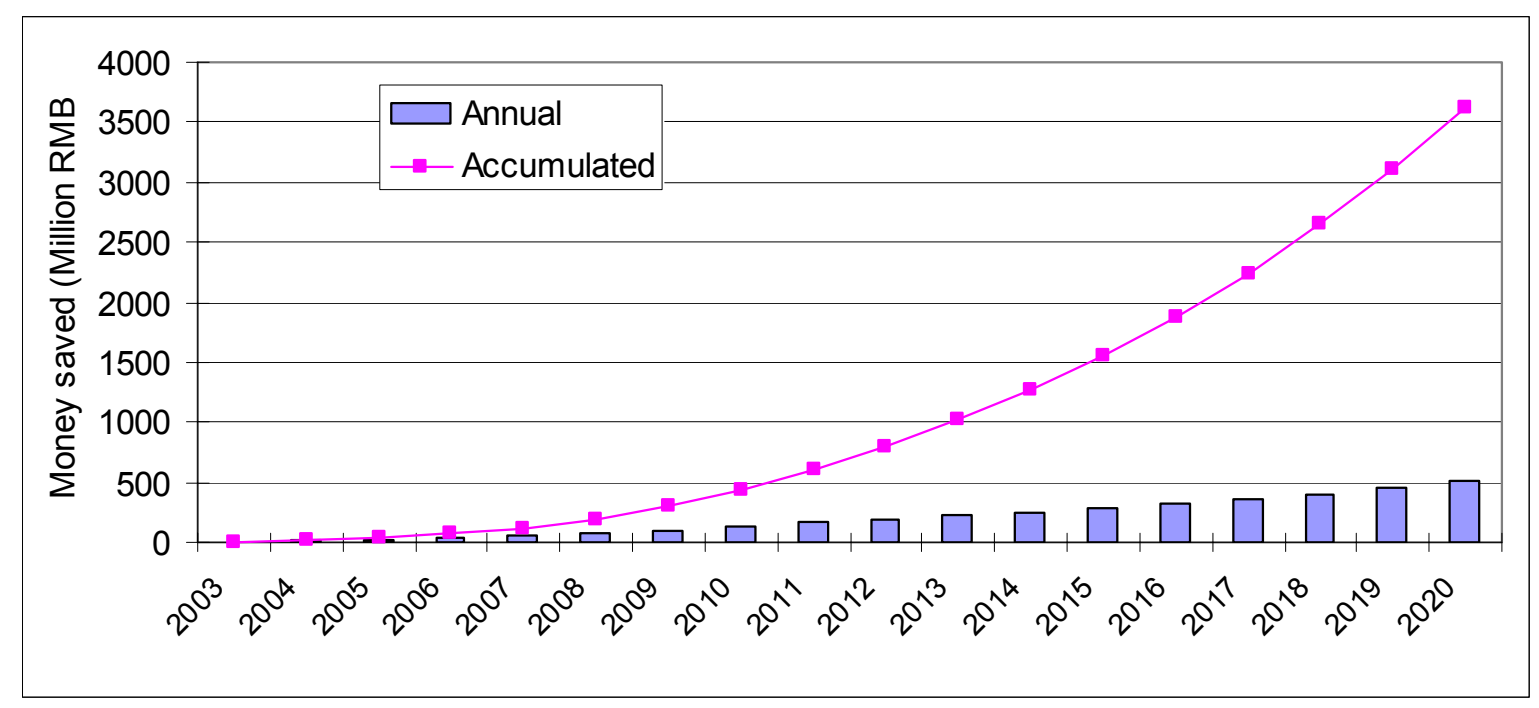

By 2020, the reduction of $\mathrm{NO}_{\mathrm{x}}, \mathrm{SO}_{2}$, and solid particulates would reach 3.7 thousand tons, 48.1 thousand tons, and 22.5 thousand tons, respectively. And the accumulated reduction of $\mathrm{NO}_{\mathrm{x}}, \mathrm{SO}_{2}$, and solid particulates would reach 25.9 thousand tons, 337.3 thousand tons, and 157.5 thousand tons from 2003 to 2020 , respectively.

Figure 10: Carbon emissions reductions due to copier labeling, 2003-2020

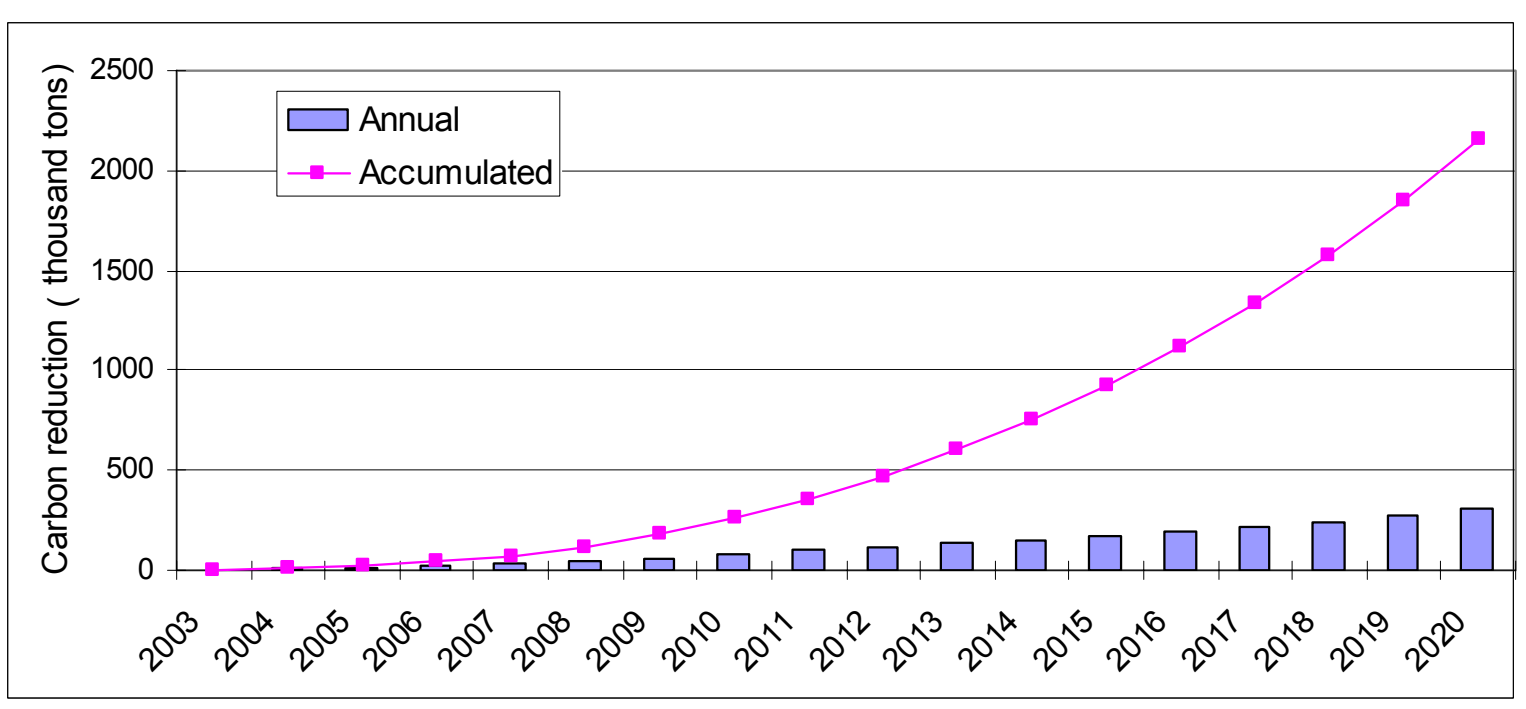


Figure 11: $\mathrm{NO}_{\mathrm{x}}$ emissions reductions due to copier labeling, 2003-2020

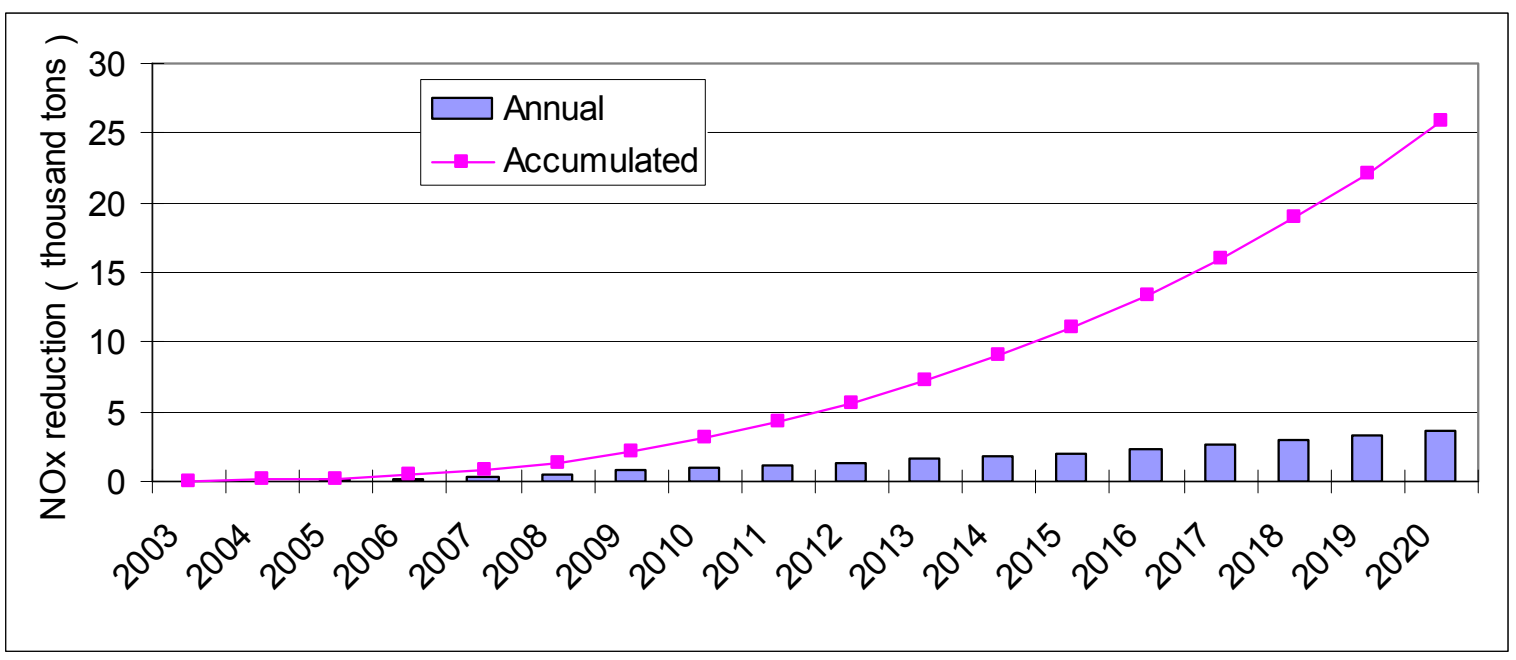

Figure 12: $\mathrm{SO}_{2}$ emissions reductions due to copier labeling, 2003-2020

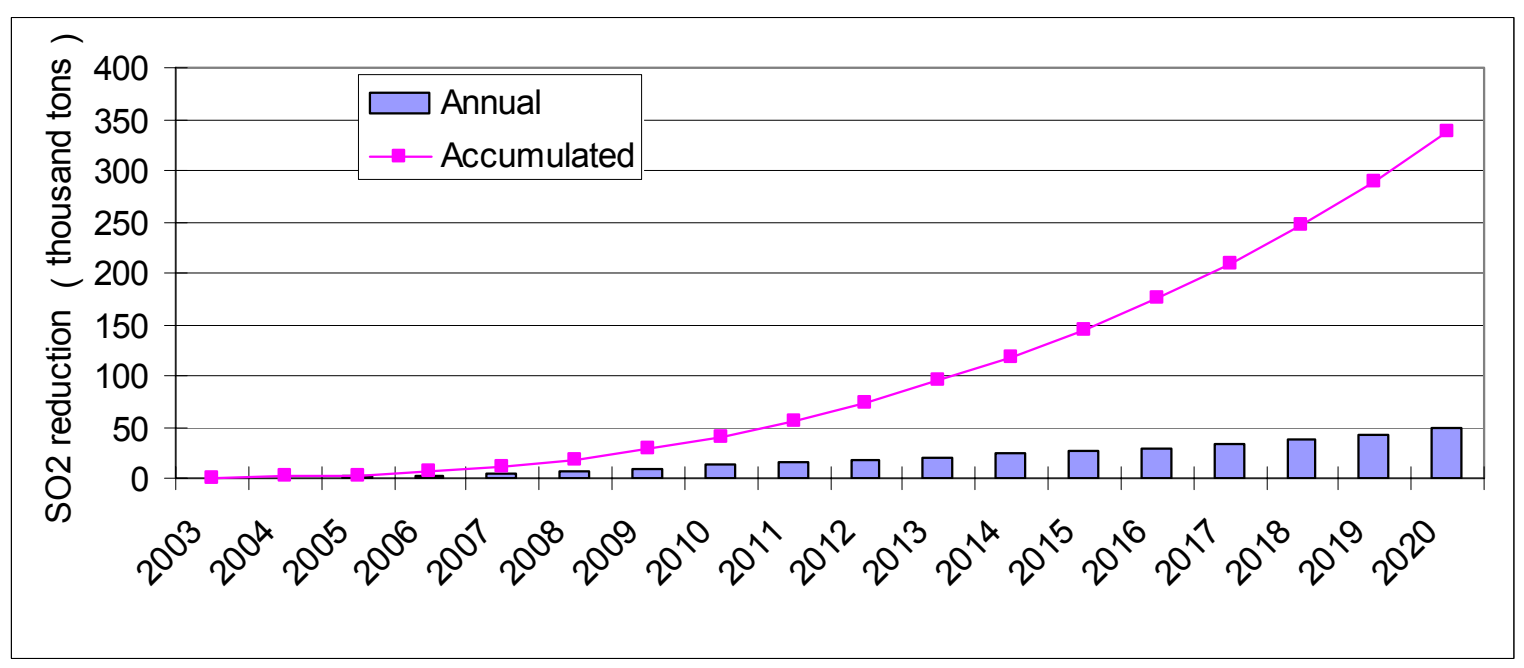


Figure 13: $\mathrm{SO}_{2}$ emissions reductions due to copier labeling, 2003-2020

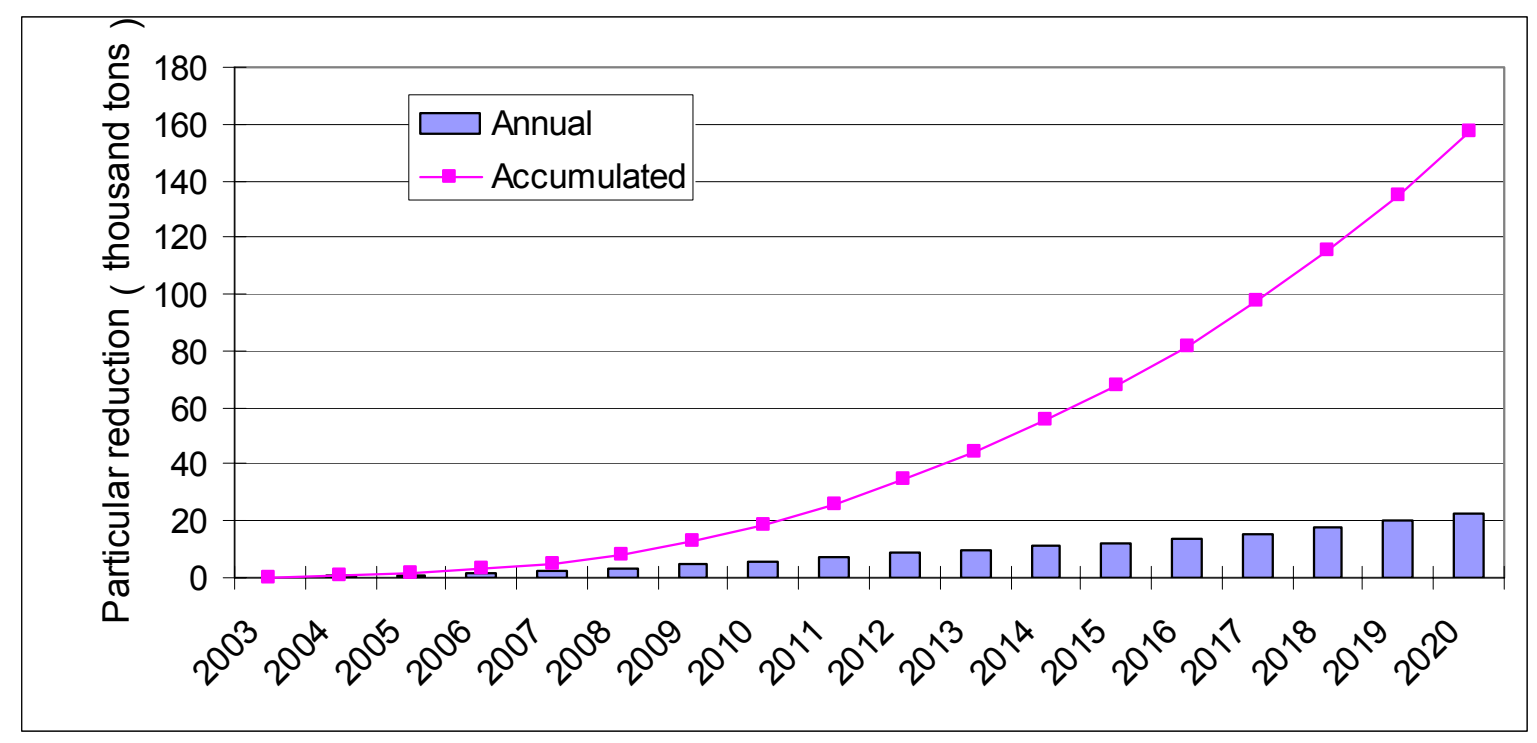

\section{Summary}

As China's economy continues to expand at a torrid pace, the penetration of office equipment and consumer electronics in China is likely to increase rapidly in the foreseeable future. So would the standby power use associated with these products. The results of this research suggest that reducing such energy waste could have huge and positive economic and environmental impacts in China. Reducing standby loss in China's growing fleet of DVD players and copiers through China's energy conservation product certification program could reduce electricity consumption by 12.9 billion $\mathrm{kWh}$ from 2003 to 2020, with a corresponding reduction of carbon emission of 4.4 million tons (table 6).

Table 6: Economic and environmental impacts of reducing standby power use in DVD/VCD players and copiers in China

\begin{tabular}{|c|c|c|c|c|}
\hline & \multicolumn{2}{|c|}{2020} & \multicolumn{2}{|c|}{$2003-2030$} \\
\hline & $\begin{array}{l}\text { DVD/VCD } \\
\text { players }\end{array}$ & Copiers & $\begin{array}{l}\text { DVD/VCD } \\
\text { players }\end{array}$ & Copiers \\
\hline $\begin{array}{l}\text { Electricity Savings } \\
\text { ( million kWh) }\end{array}$ & 635 & 906 & 6500 & 6400 \\
\hline $\begin{array}{l}\text { Cost Savings } \\
\text { (million RMB) }\end{array}$ & 362 & 500 & 3700 & 3600 \\
\hline \multicolumn{5}{|c|}{ Emissions Reductions ( 1000 tons) } \\
\hline Carbon & 215 & 307 & 2200 & 2200 \\
\hline $\mathbf{N O}_{\mathbf{x}}$ & 2.6 & 3.7 & 26.7 & 25.9 \\
\hline $\mathrm{SO}_{2}$ & 33.7 & 48.1 & 347.9 & 337.3 \\
\hline Particulars & 15.8 & 22.5 & 162.5 & $\mathbf{1 5 7 . 5}$ \\
\hline
\end{tabular}

Since China is the largest producer of many consumer electronic products, the success of reducing standby power loss in China would have an enormous impact on the world-wide effort to reduce standby power loss. 


\section{Suggested Reading:}

China National Bureau of Statistics (NBS), (2003). China Statistical Yearbook 2003, China Statistical Press, Beijing, China.

Group for Energy Efficient Appliances (GEEA) (2004).

http://www.efficient-appiances.org/About.htm

Harrington, L. and P. Kleverlaan (2001). Quantification of Residential Standby Power Consumption in Australia: Results of Recent Survey Work. Canberra, Australian Greenhouse Office.

International Energy Agency (2001). Things That Go Blip in the Night: Standby Power and How to Limit It. Paris (France), International Energy Agency.

Lebot, B., A. Meier, et al. (2000). Global Implications of Standby Power Use. ACEEE Summer Study on Energy Efficiency in Buildings, Pacific Grove CA, American Council for An Energy Efficient Economy.

Lin, Jiang; Meier, Alan, Li Tienan, and Liu Jiang, First Measurements of Standby Power Use in Chinese Homes, LBNL-49353.

Lin, Jiang, A Trickle Turns into a Flood: Standby Power Loss in China, Sinosphere, Volume 5 Issue 2, November 2002, LBNL-52669

Meier, A. and B. Lebot (1999). One Watt Initiative: a Global Effort to Reduce Leaking Electricity. Energy Efficiency and $\mathrm{CO}_{2}$ Reduction: the Dimensions of the Social Challenge, Mandelieu, France, European Council for an Energy Efficient Economy.

Nakagami, H., A. Tanaka, et al. (1997). Standby Electricity Consumption in Japanese Houses. First International Conference on Energy Efficiency in Household Appliances, Florence (Italy), Association of Italian Energy Economics.

Paolo Bertoldi, Bernard Aebischer, Charles Edlington, Craig Hershberg, Benoit Lebot, Jiang Lin, Tony Marker, Alan Meier, Hidetoshi Nakagami, Yoshiaki Shibata, Hans Paul Siderius, Carrie Webber, "Standby Losses: How Big is the Problem? What Policies and Technical Solutions Can Address It?" in the Proceedings of 2002 ACEEE Summer Studies on Energy Efficiency in Buildings, Washington, DC, LBNL-50567

Rainer, L., A. Meier, et al. (1996). Leaking Electricity in Homes. ACEEE Summer Study on Energy Efficiency in Buildings, Pacific Grove CA, American Council for an Energy-Efficient Economy.

Ross, J. P. and A. K. Meier (2001). "Measurements of Whole-House Standby Power Consumption in California Homes." Energy-The International Journal accepted for publication (2001).

Sidler, O. (2000). Campagne de Mesures sur le Fonctionnement en Veille des Appareils Domestiques. Sophia-Antipolis (France), ADEME.

United States Environmental Protection Agency (2004) Energy Star Program. http://www.energystar.gov.

Vowles, J., B. Boardman, et al. (2001). Suspecting Standby? Domestic Levels and the Potential for Household-Level Reductions in the UK. ECEEE Summer Study, Mandelieu (France), European Council for An Energy Efficient Economy.

World Bank, 1994, China: Issues and Options in Greenhouse Gas Control, Washington, DC. 